\title{
Оцінка харчового статусу дорослих осіб, які займаються фітнесом, у порівнянні з населенням України
}

\author{
О. І. Циганенко, Н. А. Склярова
}

Національний університет фізичного виховання і спорту України, Київ, Україна

\begin{abstract}
Резюме. Проведена эпидемиолого-гигиеническая оценка пищевого статуса взрослых лиц с высокой физической активностью (коэфициент физической активности - 1,7), систематически (не менее года) занимающихся фитнесом, по сравнению с остальным взрослым населением Украины. В качестве показателя состояния пищевого статуса был использован индекс массы тела (ИМТ). Установлено, что большая часть людей, систематически занимающихся фитнесом, имеют нормальный ИМТ (это 85 \% населения, для которого рекомендуется использовать здоровое питание как для категории «здоровые лица»), в отличие от взрослого населения Украины, для которого характерна недостаточная физическая активность со среднеевропейским уровнем распространения ожирения и излишней массой тела. Однако среди людей, систематически занимающихся фитнесом, выявлены и лица со сниженным ИМТ, что требует использования для них оздоровительного питания для коррекции массы тела.
\end{abstract}

Ключевые слова: статус питания, индекс массы тела, ожирение, алиментарная дистрофия, фитнес.

\begin{abstract}
Summary. Epidemiological - hygienic assessment of nutritional status was performed in adults with high level of physical activity (physical activity coefficient - 1.7) regularly (at least a year) involved in fitness classes in comparison with that in rest of adult Ukrainian population. As indicator of nutritional status was used body mass index (BMI). It was found that majority of people who regularly participate in fitness classes have normal BMI (they represent $85 \%$ of population recommended to have a healthy diet as for category "healthy persons") unlike the adult Ukrainian population, who don't get enough physical activity and have average for Europe obesity and overweight rates. Nevertheless, among people who are systematically involved in fitness classes the persons were identified with reduced $B M I$, who require the use of healthy nutrition to correct body weight.

Key words: nutritional status, body mass index, obesity, alimentary dystrophy, fitness.
\end{abstract}

Постановка проблеми. Сучасні тенденції глобальної охорони здоров'я безперервно пов'язані зі способом життя людей, дотриманням принципів здорового харчування, наявністю достатньої фрізичної активності. Сьогодні епідеміологія чотирьох класів хвороб - серцево-судинних, злоякісних новоутворювань, цукрового діабету II типу, хронічних респіраторних захворювань, що об'єднуються терміном неінфекційні захворювання, - зумовлює понад 80 \% смертей в Україні та більше 70 \% всього тягаря хвороб [2, 4-6, 9-11, 13, 15, 17, 18].

У практичному відношенні зроблено акцент на профрілактику ожиріння (та надлишкової маси тіла), серцево-судинних захворювань (та гіпертонії), цукрового діабету II типу (та метаболічного синдрому), у розвитку яких важливим фрактором ризику $\epsilon$ неадекватне харчування 3 наступним порушенням стану харчового статусу. Важливим елементом врахування стану фрактичного харчу- вання $\epsilon$ визначення за індексом маси тіла (IMT) осіб, для яких необхідно просто здорове харчування (призначене для харчування здорових людей), та людей (з надлишковою масою тіла, ожирінням різного ступеню або наявністю проявів дистрофрії аліментарного генезу тощо), до яких вже повинно застосовуватися оздоровче харчування [15, 17-23, 25, 27-29].

Згідно 3 «Глобальною стратегією ВООЗ 3 питань харчування, фрізичної активності та здоров'я: Керівництво для держав з моніторингу і оцінки виконання» (прийнята на 57-й сесії ВООЗ 22 червня 2004 р.) пріоритетним напрямком $€$ поєднання оздоровчого харчування та покращеної фрізичної (рухової) активності населення, насамперед шляхом широкого впровадження у практику фрітнесу. Це потребує проведення в кожній країні моніторингу з оцінки відповідності тривалості занять фрітнесом харчуванню дорослої людини шляхом співставлення рухової активності 
осіб, які займаються фрітнесом зі станом їх харчового статусу (як показника біологічної адекватності харчування) 3 урахуванням загальної епідеміологічної ситуації, що склалася зі станом харчування дорослого населення держави [15, 18, 25].

Таке дослідження не проводилось в Україні, і це робить його актуальним.

Зв'язок роботи 3 науковими програмами, планами, темами. Роботу виконано за НДР «Розробка системи оздоровчого харчування для осіб, які займаються фрітнесом» (№ держреєстрації 001U001736).

Мета дослідження - проведення епідеміолого-гігієнічної оцінки статусу харчування дорослих осіб з високою фрізичною активністю, які систематично займаються фрітнесом, у порівнянні з епідеміологічною ситуацією, що склалася зі станом харчового статусу та станом фрізичної активності дорослого населення України.

\section{Основні завдання роботи такі:}

- на основі даних наукової, науково-методичної літератури та інших джерел інформації провести епідеміолого-гігієнічний аналіз стану харчового статусу дорослого населення України з урахуванням його фрізичної активності у порівняльному аспекті з іншими країнами;

- провести визначення та аналіз стану харчового статусу дорослих осіб з високою фрізичною активністю, які систематично займаються фрітнесом, у порівняльному аспекті з епідеміологічною ситуацією, що склалася зі станом статусу харчування та рівнем фрізичної активності дорослого населення України.

Методи і організація дослідження. Використано метод теоретичного аналізу, який оснований на узагальненні, синтезі, екстраполяції і аналізі наукової, науково-методичної літератури та інших джерел інфоормації [1], метод оцінки стану статусу харчування (його класифрікації) за індексом маси тіла (IMT) з визначенням фактору фрізичної активності (коесріцієнту фрізичної активності) за інтенсивністю та тривалістю фрізичних навантажень за спеціальною шкалою [15].

Організація дослідження включала виконання системного аналізу та узагальнення матеріалів наукової та науково-методичної літератури, а також інших джерел інформації з питань епідеміологічних аспектів харчового статусу населення України та країн світу.

Для обстеження було обрано 140 осіб вікової групи 18-25 років (як найбільш чисельної серед відвідувачів фрітнес-центрів) 3 високою фрізичною активністю (коефіцієнт фрізичної активності $1,7)$, які систематично (не менше одного року) займаються фрітнесом. Враховано, що висока фрізична активність рекомендована експертами Всесвітньої організації охорони здоров'я (ВООЗ) та МОЗ України для здорових дорослих людей, які займаються фрітнесом [15, 18].

Всього було обстежено 84 особи чоловічої статі та 56 осіб жіночої статі. Чисельність осіб для проведення натурного епідеміолого-гігієнічного обстеження було визначено згідно з рекомендаціями ВООЗ стосовно необхідної кількості осіб для виконання натурних досліджень та спостережень [14, 18].

Результати дослідження та їх обговорення. Проведений аналіз наукової та науково-методичної літератури, а також інших джерел інформації показав, що згідно з рекомендаціями ВООЗ (а також Європейського бюро ВООЗ), програми CINDI (Coutrywide Integrated Noncommunicable Diseases Intervenseon - Загальнонаціональна інтегрована профрілактика неінфекційних захворювань) має включати епідеміологічне обстеження з визначенням харчового статусу населення, в тому числі осіб, які займаються фрізичною культурою (фрітнесом), з обчисленням величини IMT, фрактора фрізичної активності (низька, середня, висока) $[15,18]$.

Визначення харчового статусу за IMT використовується і в практиці Департаменту обстеження домогосподарств Держкомстату України згідно з відповідними методичними вказівками [3].

Результати епідеміологічних досліджень з використанням IMT як показника стану харчового статусу свідчать, що перше місце у рейтингу 3 ожиріння (IMT $=30-39,9)-3$ достатньо частим виявленням і морбідного ожиріння (IMT > 40) серед дорослого населення - займають Сполучені Штати Америки. Основним чинником виникнення такої ситуації вважають національний «фастфруд» - їжу швидкого приготування. В США першими почали застосовувати у значних масштабах «швидку їжу», і така ситуація з ожирінням у цій країні сприяла тому, що вона стала «піонером» у використанні фрітнесу $[2,6,17,18,21]$.

$\mathrm{Ha}$ другому місці за проблемами ожиріння - європейські країни. Особливо це стосується Великобританії, Греції, Румунії, Угорщини та Албанії. Саме ці держави потрапили до списку «самих товстих націй». На Кіпрі, Мальті, у Чехії, Фінляндії, Німеччині та Словаччині більше $40 \%$ дорослого населення мають ожиріння (IMT = 30-39,9). Значний відсоток населення у розглянутих країнах становлять також особи, яких відносять до категорії осіб із надлишковою масою (вагою) тіла (IMT = 25-29,9). Фіксуються і 
окремі випадки морбідного ожиріння (IMT > 40) $[17,18,21]$.

Найкраща ситуація зі станом харчового статусу спостерігається в таких державах, як Японія та Китай, для яких характерне значне превалювання нормальних величин IMT $(20-25)$ серед дорослого населення. Проте в таких країнах, як Індія, в окремих державах Центральної та Східної Афррики (наприклад, в Ефіопії), в деяких країнах Південно-Східної Азії (Таїланді, Камбоджі тощо) фріксується суттєве зниження IMT (IMT < 18,5) серед достатньо значного відсотка дорослого населення, що вказує на прояви (а в деяких випадках і на наявність при величині IMT $<16,5)$ дистрофрії аліментарного генезу $[6,11,17,18$, 21].

Значну проблему являє і стан харчового статусу у дітей, проте вона вимагає окремого розгляду і аналізу, що виходить за межі нашої публікації.

За даними Департаменту обстеження домогосподарств Держкомстату України (обстежено близько 30 тисяч дорослих осіб з розрахунком (MT), ожиріння дорослого населення в Україні (IMT $=30-39,9)$ знаходиться на середньоєвропейському рівні - $13 \%$ у чоловіків, $18 \%$ у жінок. Поширеність надмірної маси тіла (IMT = $25-29,9)$ складає $29,7 \%$ серед жінок і 14,8 \% серед чоловіків. Найбільше дорослих осіб з нормальним IMT (20-25) фріксується у віці $18-19$ років, а ожиріння (IMT $=30-39,9)$ у чоловіків і жінок спостерігається найчастіше у віці 50-59 років (тобто у віці, коли тільки незначна частина осіб може систематично займатися фрітнесом). За інфрормацією Держкомстату України, найбільше осіб з нормальним IMT мешкає у Києві, Черкаській та Волинській областях, а найбільша кількість дорослих людей з надлишковою масою тіла та 3 ожирінням проживає у Полтавській, Донецькій, Запорізькій, Херсонській та Миколаєвській областях. Взагалі ж знижений IMT (IMT < 18,5) серед дорослих не дуже характерний для населення України [16, 18]. Те, що у Києві відносно багато людей з нормальним IMT, пояснюють насамперед тим, що кияни мають високий рівень освіти і - як наслідок незначний рівень неадекватної (девіантної) харчової поведінки. А південний схід України дуже урбанізований - 3 міським стилем життя, значним використанням «їжі швидкого приготування», порушенням традицій широкого застосування домашнього (сімейного) харчування тощо [16 ].

Такий розподіл діапазонів величин IMT по регіонах пояснюють, по-перше, різним рівнем культури харчової поведінки, різним ступенем збереження традиційного «українського домашнього (сімейного)» харчування, по-друге, - різницею у рівнях урбанізації населення, по-третє, особливостями ступеня фрізичної активності, яка вища у населення $з$ історично традиційною для України трудовою діяльністю у сфері сільського господарства. Взагалі ж до 70 \% порушень у харчуванні в економічно розвинутих країнах обумовлено неадекватною (девіантною) харчовою поведінкою, що потребує проведення освітніх заходів стосовно правильного харчування серед населення (в тому числі щодо відвідувачів фрітнес-центрів) [15, 16, 25].

Детальне обстеження співробітниками Інституту кардіології імені акад. М. Д. Стражеска 1975 осіб, які постійно мешкають у Солом'янському районі м. Києва, показало, що понад третини чоловіків та чи не половина жінок віком від 18 до 64 років ведуть малорухомий спосіб життя (менше 30 хв на день помірних регулярних фрізичних навантажень). Майже половина 3 обстежених мешканців району незалежно від статі мають надлишкову вагу (масу) тіла (IMT $=25-29,9$ ), до того ж кожний восьмий чоловік і кожна п'ята жінка - ожиріння (IMT $=30-39,9)$ [4]. Проте не було проведено порівняльних досліджень стосовно мешканців міста Києва, які систематично займаються фрітнесом і мають високу фрізичну активність (інтенсивні регулярні навантаження або фрізичну роботу більше 60 хв на день).

Тому ми обстежили та визначили IMT 140 осіб (84 чоловіків та 56 жінок) вікової групи 1825 років з високою фрізичною активністю (високі фрізичні навантаження більше 60 хв на день, коефріцієнт фрізичної активності КФА $=1,7)$, які систематично займаються фрітнесом (не менше одного року).

У чоловіків знижений ІМТ був виявлений у однієї особи (1,19\%), нормальний - у $71(84,52 \%)$ особи, надмірна вага (маса тіла) - у 12 осіб $(14,29 \%)$. Всі ці люди займаються силовими видами фрітнесу, тому для них взагалі характерне деяке підвищення IMT за рахунок збільшення маси м'язів), ожиріння не було виявлено.

У жінок знижений ІМТ був виявлений у 9 осіб $(16,36 \%)$, нормальний - у $47(85,45 \%)$ осіб, випадків наявності ожиріння та надлишкової маси тіла не було виявлено.

Таким чином, величини IMT у дорослих людей (віком 18-25 років), які систематично займаються фрітнесом і мають високу фрізичну активність $(К Ф A=1,7)$, суттєво відрізняються від величин IMT, характерних (згідно 3 даними літератури та інших джерел інформації) для дорослого 
населення всієї України, а також безпосередньо для м. Києва. У тих, що систематично займаються фітнесом, виявлено значно більший відсоток осіб з нормальним IMT (85,0 \% загальної кількості; $p<0,05)$, що вказує на корисність систематичних занять фрітнесом та співпадає з даними наукової літератури, що основною метою для відвідувачів фрітнес-центрів $€$ саме покращення антропометричних показників складу тіла та стану здоров'я [7, 8, 24].

Разом з тим звертає на себе увагу наявність - особливо у жінок, які систематично займаються фрітнесом, - випадків зниженого IMT (недостатності харчового статусу), що може в перспективі негативно позначитися на стані їх здоров'я і вказує на необхідність застосування для них оздоровчого харчування. Це пояснюється тим, що для жінок взагалі характерні більше, ніж для чоловіків, надмірні вимоги до стану свого фактичного харчування (неадекватна харчова поведінка) з метою позбутися надмірної (за їх уявленнями) маси (ваги) тіла [26].

\section{Література}

1. БаскоВ А. Я. Методология научного исследования / А. Я. Басков, Н. В. Туленков. - К.: МАУП, 2004. - 215 с.

2. Біловол О. М. Ожиріння в практиці кардіолога та ендокринолога / [О. М. Біловол, О. М. Ковальова, С. С. Попова, О. Б. Тверетінов]. - Тернопіль: Укрмедкнига, 2009. C. $133-138$.

3. ВказіВки для фахівців з інтерв'ювання з питань організації та методології вибіркових обстежень населення (домогосподарств), які здійснюють органи державної статистики (в частині обстеження умов життя домогосподарств у редакції Держкомстату України № 89 від 11.04.2011р.). К.: Держкомстат України, 2011. - 107 с.

4. Горбась І. М. Епідеміологія основних фракторів ризику серцево-судинних захворювань / І. М. Горбась //Артериальная гипертензия. - 2008. - № 2 (2) - С. 5-39.

5. Вильямс $E$. $A$. Гигиенические и эпидемиологические аспекты питания и здоровья сельского населения Омской области / Е. А. Вильямс: дисс. ... канд. наук: 14.00.07. Омск: ОГМА, 2007. - 220 с.

6. ДаВиденко Н. В. Нераціональне харчування - ризик для здоров'я / [Н. В. Давиденко, І. П. Смирнова, І. М. Горбась, О. О. Кваша]. - Укр. терапевт. журн. - 2002. - Т.4, № 3. - C. 26-29.

7. Закуркин Л. В. Формирование потребностей к занятиям физической культурой у студентов технического вуза на основе рейтинговой системы оценивания / Л. В. Закуркин: автореф. дисс. ... канд. наук: 13.00.04. - Шуя: ЯГПУ, 2005. - 17 c.

8. Захаріна $\epsilon$. А. Формування мотивації до рухової активності у процесі фрізичного виховання студентів вищих начальних закладів / Є. А. Захаріна: дис. ... канд. наук: 24.00.02. - К.: НУФВСУ, 2008. - 236 с.

9. ЗуеВа Л. П. Эпидемиология: учебник / Л. П. Зуева, Р. Х. Яфраев. - М.: Фолиант, 2006. - 752 с.
У перспективі подальші дослідження будуть включати проведення дослідів 3 використання оздоровчого харчування для осіб, які систематично займаються фрітнесом, але при цьому мають знижені IMT.

\section{Висновки}

1. Проведений аналіз наукової, науково-методичної літератури та інших джерел інфрормації показав, що дієвим шляхом вирішення проблеми ожиріння та надлишкової маси тіла $є$ поєднання харчування оздоровчого спрямування 3 заняттями фітнесом.

2. Встановлено, що при систематичних заняттях фрітнесом має місце значно більший, за умов високої фрізичної активності, відсоток дорослих осіб з нормальним IMT ( $і$ для яких необхідне використання здорового харчування) у порівнянні з дорослим населенням як всієї України, так і м. Києва.

3. Для осіб, які систематично займаються фрітнесом і мають знижений IMT, необхідне використання оздоровчого харчування.

\section{References}

1. Baskov A. Ya. Methodology of scientific research / A. Ya. Baskov, N. V. Tulenkov. - Kiev: IAPM, 2004. - 215 p.

2. Bilovol A. M. Obesity in the practice of cardiologist and endocrinologist / [O. M. Bilovol, O. N. Kovaliov, S. S. Popov, O. B. Tveretinov]. - Ternopil: Ukrmedknyha, 2009. P. $133-138$.

3. Guidelines for interviewing experts on the organization and methodology of sample surveys of population (households), that are carried out by governmental statistics establishments (as concerns household living conditions surveys in the wording of the State Statistics Committee of Ukraine N 89 of 11.04.2011). - Kyiv: State Statistics Committee of Ukraine. 2011. - 107 p.

4. Gorbas I. M. Epidemiology of major risk factors for cardiovascular disease / I. M. Gorbas // Arterialnaia hipertensia. - 2008. - N 2 (2). - P. 5-39.

5. Williams Ye. A. Sanitary and epidemiological aspects of nutrition and health in rural population of Omsk Region / Ye. A. Williams: diss. ... Cand. of Sci.: 14.00.07. - Omsk: OSMA, 2007. - 220 p.

6. Davydenko N.V. Improper nutrition is health risk / [N. V. Davydenko, I. P. Smirnova, I.M. Gorbas, O. O. Kvasha]. - Ukr. Terapevtychnyi Zhurnal. - 2002. Vol. 4, N 3. - P. 26-29.

7. Zakurkin L. V. Formation of the needs for physical training in a technical college students based on the rating assessment system / L. V. Zakurkin: Authoref. of diss. ... Cand. of Sci.: 13.00.04. - Shuya: YAGPU 2005. - 17 p.

8. Zakharina Ye. A. Development of motivation for physical activity during physical education in students of higher educational institutions / Ye. A. Zakharina: dis. ... Cand. of Sci.: 24.00.02. - Kiev: NUPESU, 2008. - 236 p.

9. Zuieva L. P. Epidemiology: textbook / L. P. Zuieva, R. Kh. Yafaiev. - Moscow: Foliant, 2006. - 752 p. 
10. Коваленко В. М. Харчування і хвороби системи кровообігу: соціальні і медичні проблеми // Журн. Акад. мед. наук України. - 2002. - Т. 8, № 4. - С. 685-692.

11. Лanmeßa E. H. Особенности лечебного питания больных с алиментарной дистрофией (белково-энергетической недостаточностью алиментарного генеза)/Е. Н. Лаптева // Вопр. здорового и диет. питания. - 2011. № 11. - C. 4-15.

12. Лисицкая T. С. Социологический анализ доминирующих мотиваций занимающихся в фитнес-клубах / Т. С. Лисицкая, С. И. Кувшинова // Теория и практика физ. культуры. - 2004. - № 2. - С. 37-40.

13. Мальцев С. В. Показатели физического развития и белково - энергетического статуса у здоровых подростков при дефиците массы тела в Республике Татарстан / С. В Мальцев / / Рос. вестн. перинатологии и педиатрии. 2006. - T. 54, № 6. - С. 92-98.

14. Мамаев А. Н. Основы медицинской статистики / А. Н. Мамаев: учебн. пособие. - М.: Здоровье, 2011. $128 \mathrm{c}$.

15. Методичні рекомендації для лікарів загальної практики - сімейної медицини з приводу консультування пацієнтів щодо основних засад здорового харчування / [укл. А. Григоренко (Затв. наказом МОЗ України № 15 від 14.01.2013р.). - К.: МОЗ України, 2013. -28 с.

16. Обстеження умов життя домогосподарів. Департамент обстеження домогосподарів Держкомстату України [Електронний ресурс]. - Режим доступу: www.ukrstat.org. html.

17. Ожирение / под ред. И. И. Дедова, Г. И. Мельниченко. - М.: Мед. инорорм. центр, 2004. - С. 16-43.

18. Питание при алиментарных заболеваниях. Информационная система анализа в области питания (NLIS) [Электронный ресурс] - Режим доступа: www. who. int/ nutrihion/nlis. html.

19. Рубина E. А. Санитария и гигиена питания: учебник / Е. А. Рубина. - М.: Академия, 2005. - 288 с.

20. Руденко С. В. Врачебный контроль в фитнесе: монограсия / С. В. Руденко. - М.: Сов. спорт, 2009. 192 c.

21. Савельев Л. В. Современная концепция лечения ожирения: клинические рекомендации для практикующих врачей / Л. В. Савельева // Фарматека. - 2007. № 12. - С. 33-38.

22. Седлецкий Ю. И. Современные методы лечения ожирения. Руководство для врачей/Ю. И. Седлецкий. СПб.: Здоровье, 2007. - 416 с.

23. СкорнякоВа А. Медифит. Фитнес-технологии: пособ. / А. Скорнякова, В. Горбунов. - М.: Медифит, 2009. $200 \mathrm{c}$.

24. ТВеліна А. Мотивація та інтерес до занять з фрітнесу студентів спеціальності «різична культура» / А. Твеліна, Т. Тарасова // Молода спортивна наука України. 2008. - Т. 4, Вип. 8. - С. $218-221$.

25. Цыганенко О. И. Концепция системы оздоровительного (функционального) питания в фритнесе / О. И. Цыганенко // Педагогіка, психологія та медико-біологічні проблеми фрізичного виховання і спорту. - 2011. - № 5. C. $107-110$.

26. Цыганенко О. И. Проблема неадекватного (девиантного) пищевого поведения лиц, занимающихся фритнесом и при проведении фризической реабилитации как составляющей оздоровительных фитнес-программ / О. И. Цыганенко, Я. В. Першегуба, О. Л. Паладина // Физ. воспитание студентов. 2013. - № 2. - С. 63-68.
10. Kovalenko V. M. Nutrition and cardiovascular diseases: the social and health problems // Zhurnal Akademii medychnykh nauk Ukrainy. - 2002. - Vol. 8, N 4. P. 685-692.

11. Lapteva Ye. N. Feature of nutritional therapy for patients with alimentary dystrophy (protein-calorie deficiency of alimentary origin) / Ye. N. Lapteva / / Voprosy zdorovogo i dieticheskogo pitania. - 2011. - N 11. - P. 4-15.

12. Lisitskaia T. S. Sociological analysis of dominated motivations of people engaged in fitness clubs / T. S. Lisitskaia, S. I. Kuvshinova // Theory and Practice of Physical Culture. - 2004. - N 2. - P. 37-40.

13. Maltsev S. V. Indicators of physical development and protein-calorie status in healthy adolescents with a deficit of body weight in the Republic of Tatarstan / S. V. Maltsev // Rociiskii Zhurnal perinatologii i pediatrii. - 2006. - Vol. 54, N 6. - P. 92-98.

14. Mamaev A. N. Principles of medical statistics: stady guide / A. N. Mamaev. - Moscow: Zdorovie, 2011. - 128 p.

15. Guidelines for general practicioners and family therapists for patient counseling on basic principles of healthy eating / [Composed by A. Grigorenko (approved by order of the Ministry of Healthcare of Ukraine N 15 of 01.14.2013)]. - Kiev: Ministry of Healthcare of Ukraine, 2013. - 28 p.

16. Survey live conditions of households. Department of households surveys of State Statistics Committee of Ukraine [Electronic resource]. - Mode of access: www.ukrstat.org. html.

17. Obesity / Ed. by I.I. Dedov, G. I. Melnichenko. Moscow: Medical Information Centre, 2004. - P. 16-43.

18. Nutrition in the treating of eating disorders. Information system for analysis in the field of nutrition (NLIS) [electronic resource] - Access mode: www.who.int/nutrihion/ nlis.html.

19. Rubina Ye.A. Sanitation and nutritional hygiene: textbook. / Ye. A. Rubina. - Moscow: Akademia, 2005. 288.

20. Rudenko S. V. Medical supervision in fitness: monograph / S. V. Rudenko. - Moscow: Soviet Sport, 2009. $-192 \mathrm{p}$.

21. Saveliev L. V. The modern concept of the treatment of obesity: clinical guidelines for practitioners / L. V. Saveliev // Farmateka. - 2007. - N 12. - P. 33-38.

22. Sedletskii Yu. l. Current methods for treating obesity. Guide for physicians / Yu. I. Sedletskii. - Saint-Petersburg: Zdorovie, 2007. - $416 \mathrm{p}$.

23. Skorniakova A. Medifit. Fitness technologies: manual / A. Skorniakova, V. Gorbunov. - Moscow: Medifit, 2009. $200 \mathrm{p}$.

24. Tvelina A. Motivation and interest for fitness classes in students of specialty «physical culture» / A. Tvelina, Tarasova T. // Young Sports Science of Ukraine. - 2008. - Vol. 4, Vyp. 8. - P. 218-221.

25. Tsyganenko $O$. I. The concept of the system of remedial (functional) nutrition in fitness. / O. I. Tsyganenko // Pedagogics, psychology and medical-biologic problems of physical training and sports. - 2011. - N 5. - P. 107110.

26. Tsyganenko 0 . I. The problem of inadequate (deviant) eating behavior in people involved in fitness classes and during physical rehabilitation as a part of health and fitness programs, and its solution / [O. I. Tsyganenko, Ya. V. Persheguba, O. L. Paladina, N. A. Skliarova et al.] // Fizicheskoe vospitanie studentov. - 2013. - N 2. P. 63-68. 
27. Boekh-Behrens W. U. Gesundheitsorientiertes Fitnesstraining / W. U. Boekh-Behrens, W. Buskies. - Dr. Loges + Co Gimbh, Winsen, 2002. - 350 p.

28. Lopez C. Estimated intelligtnce quotient in anorexia nervosa a systematic rewiew meta - analysis of the literature / C. Lopez, D. Stahl, K. Tchanturia //Annals Psihiatry. 2010. - Vol. 9 - P. 305 - 312.

29. Hilbert $A$. Maintenance of binge eating through negative mood: a naturalistic comparison of binge eating disorder and bulimia nervosa / A. Hilbert, B. Tuschen-Caffier // International Journal of Eating Disorders. - 2007. - Vol. 40, N 6. - P. 521-530.
27. Boekh-Behrens W. U. Gesundheitsorientiertes Fitnesstraining / W. U. Boekh-Behrens, W. Buskies. - Dr. Loges + Co Gimbh, Winsen, 2002. - 350 p.

28. Lopez C. Estimated intelligence quotient in anorexia nervosa a systematic review meta - analysis of the literature / C. Lopez, D. Stahl, K. Tchanturia // Annals Psychiatry 2010. - Vol. 9. - P. 305-312.

29. Hilbert $A$. Maintenance of binge eating through negative mood: a naturalistic comparison of binge eating disorder and bulimia nervosa / A. Hilbert, B. Tuschen-Caffier // International Journal of Eating Disorders. - 2007. Vol. 40, N 6. - P. 521-530.

Надійшла 14.03.2013 